8. Nowotny, M. Increasing the ketone selectivity of the cobalt-catalyzed radical chain oxidation of cyclohexane [Text] / M. Nowotny, L. N. Pedersen, U. Hanefeld, T. Maschmeyer // Chemistry. 2002. - Vol. 8, No. 16. - P. 3724-3731. doi:10.1002/15213765(20020816)8:16<3724::aid-chem3724>3.0.co;2-w

9. Ludyn, A. M. The impact of amino acids on cyclohexane oxidation [Text] / A. M. Ludyn, V. V. Reutskyy // Bulletin of the Lviv Polytechnic National University. Series of Chemistry, Materials Technology and Their Application. - 2016. Vol. 841. - P. 108-112.

10. Reutskyy, V. Okysnennia tsykloheksanu v prysutnosti bahatoatomnykh spyrtiv [Text] / V. Reutskyy, O. Ivashchuk, S. Mudryi, O. Suprun // Materialy mizhnarodnoi naukovoi konferentsii, prysviachenoi 100-richchiu vid dnia narodzhennia profesora Dmytra Tolopka «Aktualni problemy khimii ta tekhnolohii orhanichnykh rechovyn (APCTOS)», Lviv, Ukraine, November 6-8, 2012. - Lviv: Vydavnytstvo Lvivskoi politekhniky, 2012. - P. 24.

11. Christopher, R. Oxidation of Cyclohexane by Transition Metal Oxides on Zeolites [Text] / R. Christopher, R. Riley, E. N. Montgomery, N. N. Megally, A. J. Gunn, L. S. Davis // The Open Catalysis Journal. - 2012. - Vol. 5, No. 1. - P. 8-13. doi:10.2174/ 1876214x01205010008

12. Novye kataliticheskie kompozitsii dlia selektivnogo okisleniia uglevodorodov na osnove soedinenii metalov peremennoi valentnosti i katalizatorov mezhfaznogo perenosa [Text] // Tezisy dokladov 7-go Neftehimicheskogo simpoziuma. - Kyiv, 1990. - 230 p.
13. Reutskyy, V. V. Kataliticheskoe okislenie tsiklogeksana v akusticheskom pole [Text]: PhD thesis / V. V. Reutskyy. - Lviv, 1988. - 119 p.

\section{УСОВЕРШЕНСТВОВАНИЕ ПРОЦЕССА ОКИСЛЕНИЯ ЦИКЛОГЕКСАНА}

Рассмотрен способ усовершенствования процесса жидкофазного окисления циклогексана. Определен положительный эффект кислородосодержащей добавки - Бис-2 цианетилового этера - на основные технико-экономические показатели процесса - конверсию сырья, селективность по продуктах окисления и соотношение целевых продуктов. Исследовано оптимальное соотношение компонентов бинарной каталитической системы Предложен комплексный метод использования продуктов окисления циклогексана путем утилизации полученных побочных кислот эстерификацией их со спиртами.

ключевъе слова: окисление циклогексана, кислородосодержащая добавка, бинарная каталитическая система, конверсия сырья.

Ludyn Anatoly, PhD, Associate Professor, Department of the Theory of Organic Products, National University «Lviv Polytechnic», Ukraine, e-mail: anatolii.m/ludyn@lpnu.ua, ORCID: https://orcid.org/ 0000-0002-5555-687X

Reutskyy Viktor, Doctor of Technical Sciences, Associate Professor, Department of the Theory of Organic Products, National University «Lviv Polytechnic», Ukraine, e-mail: reutskyy@polynet.lviv.ua, ORCID: https://orcid.org/0000-0002-7388-1115

\section{Tkachenko N., Vikul 5., Sevastyanova E., Dets $\mathbf{N}$., Honcharuk Ya.}

\title{
SUBSTANTIATION OF THE COMPOSITION OF PROBIOTIC COSMETIC PRODUCTS FOR THE TONING OF OILY SKIN
}

Показана доцільність застосування пробіотиків у натуральній косметиці. Обгрунтовано оптимальні масові частки кислої сироватки та екстракту квітів Tagetes patula (59,98 та 40,02 \% відповідно) як компонентів пробіотичного косметичного засобу для тонізачії жирної шкіри. Доведено, що розроблений пробіотичний косметичний лосьйон натуральний, безпечний, характеризується високими органолептичними, нормованими фізико-хімічними показниками, покращеними мікробіологічними характеристиками.

Ключові слова: пробіотична косметика, тонізація шкіри, Bifidobacterium, Lactobacillus, водноспиртовий екстракт, Tagetes patula, кисла сироватка.

\section{Introduction}

Skin is the largest organ in the human body, which is in constant work throughout life. The condition of the skin largely depends on age, nutrition and lifestyle. The main function of the skin is protection of the human body from external influences, creating a physical barrier. In addition, the skin also performs additional functions, which include: regulating body temperature, controlling sweating, feeling, keeping lipids and water. Acting as a barrier and a link between internal organs and the external environment, the skin is always in contact with various substances. A healthy and blooming skin is the result of well-being and constant care [1].
The face is the most open part of the skin of a person, his business card. This is the first thing that they pay attention to when they meet. In order for the face to remain beautiful, fresh and attractive, special care is needed. The skin of the face is constantly exposed to the negative effects of various external factors. In addition, it shows signs of fatigue, physical overload and stress. Over time, the skin loses its freshness, wrinkles appear on it, it dims and becomes less attractive [2].

Facial skin care involves a number of procedures: washing, cleansing, nutrition, moisturizing, toning. To care for a specific type of facial skin, it is necessary to choose the right cosmetic products. If the means for washing and moisturizing 
creams are used by almost everyone, the products for toning are an insignificant part of consumers. And this phase of withdrawal is not less important, since after washing the face with the use of various means, the active acidity of the facial skin shifts to the alkaline side. The best means for toning the skin of the face are tonics, tonic lotions and cosmetic lotions [2, 3]. Tonics and lotions have a positive effect on the face [2-5]:

- perform a protective function, neutralizing the effect

of hard water on the skin;

- normalize the level of acidity $(\mathrm{pH})$;

- have antiseptic effect, destroy harmful microorganisms; - nourish the skin with antioxidants, these active compounds help slows down the aging process of the skin; - remove puffiness and redness from the skin;

- improve the effect of day and night creams, providing better penetration into the epidermis;

- improve blood circulation in the skin of the face; - smoothen mimic wrinkles.

The basis of lotions and tonics is mineral water. It is the quality of mineral water that largely determines the quality of these cosmetic products [2, 3]. Leading enterprises for the production of tonics recommend the use of French mineral waters - «Evian», «Perrier», «Vittel», etc., as the basis [3]. An alternative to these types of highquality mineral water can be the mineral waters of the Carpathians, the Caucasus, as well as mineral waters for baby food. In addition to mineral water, lotions and tonics contain the following components [2]:

- ethyl alcohol is the basis of these cosmetic products. Alcohol expands the pores, helps to exfoliate excess elements from the skin. The amount of alcohol depends on the characteristics of cosmetic products: according to DSTU 4093-2002 «Cosmetic Lotions and Tonic» [6] tonics contain $0-8 \%$ of ethyl alcohol; lotion-tonics and cosmetic lotions $-8.1-20.0$ and 20.1-80.0\%, respectively. For oily skin use a product with a high alcohol content (its concentration can reach up to $50 \%$ ). Given this fact, all types of cosmetics can be recommended for oily skin according to $[2,6]$;

- matting agent is the main active component of tonics and lotions. It moisturizes and tones the skin, ensures its smooth tone, protects from irritation. The effect of this component is not more than three hours;

- additional nutrients are optional components of lotions and tonics, therefore each firm independently approaches to their choice. As a rule, these components play the role of flavors and/or colorants, but of natural origin. Typically, as nutrients used ethereal and vegetable oils, medicinal plants, panthenol, vitamins. In the composition of tonics and lotions for oily skin, vegetable oils are not added, and essential oils are added only when other components of the tonic or lotion do not create a pleasant aroma in it [2, 3]. Often, in order to ensure a pleasant color and aroma in these cosmetics, as well as to enrich the bio-antioxidants, extracts of medicinal plants are added to their composition;

- salicylic acid. This component is also optional. It is indicated on the package. Tonic and lotions with salicylic acid have an antibacterial effect, most often with salicylic acid use for facial rashes, acne. Typically, salicylic acid is added to cosmetic lotions with a high content of ethyl alcohol, since the antibacterial effect in these cosmetics is due to the increased concentration of the latter. Tonics without alcohol or with a low content of it, usually produce with the addition of salicylic acid to provide an antibacterial effect.

Today, the world's leading scientists in the field of cosmetology argue that the use of antibacterial chemicals in cosmetics leads to the destruction of not only harmful but also beneficial microflora of the skin, violates its microbiome [7]. Therefore, it is necessary to give preference to the use of natural cosmetics, which does not contain antibacterial components. An alternative to the use of antibacterial components in tonics and lotions can be the use of live cultures of probiotic microorganisms (Lactobacillus acidophilus and Bifidobacterium), which have high antagonistic properties with respect to the pathogenic and opportunistic microflora.

As a rule, the normalization of the acidity level of the facial skin is carried out by the addition of organic acids (in particular, lactic, glycolic, tartaric, malic, citric, pyruvic, and also the above salicylic acid). The amount of organic acids in the tonics for oily skin should not exceed $3 \%$ [2-5].

Given the above information, it can be argued that the innovative alternative for the development of lotions and tonics can be the use of illuminated milk whey fermented with probiotic microorganisms as a basis in these cosmetics. This will create probiotic cosmetic products from secondary dairy raw materials containing a unique complex of macro- and microelements, cheaper from mineral water and in large quantities remains now not processed at dairy enterprises. For the enrichment of probiotic cosmetics, matting substances, in particular, bioantioxidants with antiseptic action, it is advisable to use extracts of medicinal plants - marigolds, which have long been common in Ukraine [2, 8]. Thus, the development of probiotic cosmetics for the toning of facial skin on the basis of illuminated milk whey, fermented probiotic cultures, and marigold extracts is an urgent task.

\section{The object of research and its technological audit}

The object of research is a probiotic tonic for oily skin, produced with the use of acidic whey, a water-alcohol extract of dried flowers Tagetes patula and mineral water «Malyatko».

For carrying out of experimental researches as raw material used:

- curd whey obtained by «Gormolzavod No. 1» LLC (Odessa, Ukraine) in the production of cottage cheese in accordance with DSTU 4554:2006 [9];

- mineral water «Malyatko», which has a balanced composition of macro- and microelements provided for the research of «Ekonia» LLC FDI (Zolotonosha, Cherkasy region, Ukraine);

- shredded dried flowers Tagetes patula (manufacturer - LLC «Tsiliushchi roslyny» (Kropivnitsky, Ukraine) together with the company «Soyuz Afgan»);

- rectified ethyl alcohol of the brand «Extra» according to DSTU 4221:2003;

- direct bacterial concentrate of FD DVS ABT-2, provided for research by «Christian Hansen Ukraine» LLC (Kyiv, Ukraine).

Sour whey is obtained as follows: whey obtained at «Gormolzavod No. 1» LLC (Odessa, Ukraine) in the production 
of cottage cheese (active whey acidity 4.5-4.6 units $\mathrm{PH}$ ), heated to a temperature of $95{ }^{\circ} \mathrm{C}$ and held for 5 minutes for denaturation of whey proteins. Denatured whey proteins are separated using a five-layer lavsan filter, after which the protein mass is cooled to a temperature of $2-6{ }^{\circ} \mathrm{C}$ and transferred to produce protein dairy products or short chain peptides for cosmetic products with an anti-age effect. The illuminated whey is cooled to a temperature of $37{ }^{\circ} \mathrm{C}$ and fermented with mixed cultures of lacto- and bifidobacteria as part of the direct bacterial concentrate FD DVS ABT-2. This bacterial concentrate contains monocultures of Bifidobacterium animalis $B b-12$ and mixed cultures of lactobacilli - Lactobacillus acidophilus La-5 + Streptococcus thermophilus. Two of the three cultures Bifidobacterium animalis $B b-12$ and Lactobacillus acidophilus $L a-5$ are recognized classical probiotics with a clinically proven probiotic effect on the human body. The amount of bacterial concentrate is $100 \mathrm{c}$. u. per $1000 \mathrm{~kg}$ of fermented illuminated whey is provided the initial concentration of monocultures of Bifidobacterium animalis $B b-12$ and mixed cultures of Lactobacillus acidophilus La-5 + Streptococcus thermophilus $1 \cdot 10^{6} \mathrm{CFU} / \mathrm{cm}^{3}$. Fermentation of the illuminated whey is carried out for 48 hours at a temperature of $37{ }^{\circ} \mathrm{C}$, optimal for the development of probiotic cultures of lactobacilli and bifidobacteria. In the resulting acidic whey, the concentration of viable cells of Lactobacillus acidophilus La-5 + Streptococcus thermophilus is $(4.0-5.0) \cdot 10^{8} \mathrm{CFU} / \mathrm{cm}^{3}$, the concentration of Bifidobacterium animalis $\mathrm{Bb}-12(1.8-3.6) \cdot 10^{8} \mathrm{CFU} / \mathrm{cm}^{3}$, titrated acidity $-(12 \pm 1)^{\circ} \mathrm{T}$, active acidity $-(4.31 \pm 0.01) \mathrm{pH}$ units.

A water-alcohol extract of dried flowers Tagetes patula is prepared according to the extraction mode developed by the authors: the content of ethyl alcohol in water-alcohol solution is $75 \%$, the ratio «water-alcohol solution: dry flowers Tagetes patula» is 70, the extraction time of BAS from marigold flowers is $45 \mathrm{~min}$. The obtained extract contains $24.7 \mathrm{mg} / 100 \mathrm{~g}$ carotenoids, $87.2 \mu \mathrm{g} / 100 \mathrm{~g}$ catechins, $627.5 \mu \mathrm{g} / 100 \mathrm{~g}$ flavonoids and has an antioxidant activity of $183.3 \pm 1.3$ act. units.

The rationale for the optimal proportions of acid whey, a water-alcohol extract of dry colors Tagetes patula and mineral water «Malyatko» as part of a probiotic cosmetic for toning of oily skin is performed in the software package Statistica 10 (StatSoft, Inc., USA).

\section{The aim and objectives of research}

The aim of research is optimization of the component composition of the probiotic cosmetic agent for toning of oily skin.

To achieve this aim, the following tasks are solved:

1. To determine the antioxidant activity and active acidity of probiotic cosmetics for toning of oily skin with various proportions of raw ingredients - acid whey obtained with the use of probiotic cultures of lacto- and bifidobacteria, an extract of dried flowers Tagetes patula and mineral water «Malyatko».

2. To establish the optimum ratio of raw ingredients, in which the probiotic cosmetic for toning of oily skin has the maximum antioxidant activity and the normalized value of active acidity.

3. To determine the quality indicators of a probiotic cosmetic agent for toning of oily skin, produced using raw ingredients in the optimal ratio.

\section{Research of existing solutions of the problem}

Toning cosmetics for oily skin, in addition to the listed general effects, should provide a narrowing of the skin pores, removing fatty gloss and acne [2-5]. Usually, these cosmetic products include [2, 4]: mineral water, herbal extracts, matting substances, in particular essential oils, ethyl alcohol (from 5 to $30 \%$ ). To improve the appearance of the epidermis, the cosmetic agent must influence the biochemical processes that take place in the dermis. But for this it is necessary to destroy the lipid layer, glue the horny scales of the epidermis. To dissolve fat-like lipids, the composition of cosmetics can add [10]:

- surfactants that dissolve lipids and clear the way into the dermis for active substances, but also open the way to bacteria (on the label can be listed as emulsifiers); - soft surfactants. To preserve the skin barrier, surfactants are used, for example coconut oil. These highquality soft surfactants differ in structure from those of traditional surfactants and the penetration of molecules through the stratum corneum is minimized, and the surfactant structure data molecule does not allow them to react with lipids and proteins of the stratum corneum;

- AHA and BHA (beta-hydroxyl and alpha-hydroxyl acid). Remove dead skin cells and maintain a natural balance of skin oils that provide it with moisture. Likewise, the action of lactic, glycolic, tartaric, malic, citric, salicylic, pyruvic acids.

To obtain a natural source of macro- and microelements and lactic acid in the work is offered by using as a basis for probiotic cosmetics of acidic whey. The investigated acid whey contains a high concentration of probiotic cultures of lacto- and bifidobacteria (not less than $1 \cdot 10^{8} \mathrm{CF} / \mathrm{cm}^{3}$ ) and $0.99 \pm 0.2 \%$ lactic acid.

Today, world scientists claim the benefits of cosmetic products produced with the use of lysates of probiotic bacteria. Thus, in [11-14] positive influence of lysates of probiotic cultures Lactobacillus delbreuckii, Lactobacillus rhamnosus, Lactobacillus salivarius, Lactobacillus paracasei, Bacillus subtilis in cosmetic products in the treatment of atopic dermatitis is noted. It should be noted that the lysates of Lactobacillus delbreuckii cultures have contributed to the inhibition of atopic dermatitis [12], whereas Bacillus subtilis lysates are recommended for prevention of atopic lesions [11], and lysates of Lactobacillus salivarius, Lactobacillus rhamnosus, Lactobacillus paracasei for therapy in atopic dermatitis [13, 14].

Some scientists have investigated the effect of probiotic lysates on acne: a clinical improvement in skin condition with acne is noted with the use of Lactobacillus acidophilus and Lactobacillus bulgaricus lysates [15]. Lysates of bacteria of the Bifidobacterium species provide prevention of skin disorders associated with immune abnormalities, and also improve the condition of sensitive skin [16]. Mitigate inflammation and reduce the sensitivity of the skin lysates of Lactobacillus delbreuckii and Lactobacillus casei $[17,18]$. The lysates of Lactobacillus paracasei cultures [19] accelerate the restoration of skin barrier functions [19], lactates of Lactobacillus rhamnosus provide prevention of skin lesions by ultraviolet [20], and lactates of Lactobacillus reuteri protect epidermal keratinocytes [21]. Lysates of mixed cultures of Lactobacillus bulgaricus + Streptococcus 
thermophilus in combination with prebiotics Inulin contribute to a $70 \%$ reduction in the Staphylococcus aureus population within 24 hours on the skin and stimulate the growth of the natural microflora of the skin microbioma cultures of Staphylococcus epidermidis [22].

Given the known today information about the beneficial properties of the probiotic cultures of Lactobacillus and Bifidobacterium, it can be assumed that probiotic lotions and tonics based on acidic whey with living cells of these bacteria will contribute not only to toning the skin, but also to creating a natural barrier for penetration of foreign microflora into the pores. An extraneous microflora can cause skin irritation, the appearance of «acne» and others. Therefore, such means for toning the skin can be $100 \%$ natural, that is, without the addition of antimicrobials, and lactic acid in the composition of probiotic acid whey enhance the antibacterial effect of probiotic tonics and lotions.

As a natural source of bioantioxidants, the authors propose to use a water-alcohol extract of dried flowers Tagetes patula. Of the known properties of marigolds [8, 23] (the Latin name Tagetes) in cosmetic means for toning the skin, anti-inflammatory, antiseptic, antiviral and tonic properties are essential. The phytoncidal properties of marigolds ensure their insecticidal value. The above-ground part of Tagetes is rich in essential oil of yellow or amber hue with floral-spicy and fruity aroma, the main component of which is the ocimene, which share is about $50 \%$. The oils also contain sabinene, apinene, limonocene, citral, myrcene, linalool, thymol, terpinene and other components that inhibit the growth and development of pathogenic microorganisms and fungi. BASs found in the aerial part of the plant have antiviral activity and are harmful to many strains of pathogenic bacteria and viruses [24-27].

Carotenoids, in particular lutein, contained in the flowers of marigolds, have anti-inflammatory properties, reduce the risk of cataract development, contribute to the recovery of visual acuity, especially in people with constant vision [28, 29].

Of all the groups of natural compounds identified in the flowers of marigolds, flavonoids occupy a special place, which indirectly through enzyme systems regulate the processes that determine, first of all, the state of the cell membrane, and provide antioxidant, anti-inflammatory and wound-healing action. The wide spectrum of the action of flavonoids is explained by their selectivity to reactive oxygen species (ROS): in ROS hyperproduction they exhibit antioxidant properties, and at a low level of ROS generation - prooxidant. The main flavonoids in the colors Tagetes patula (patchwork patches) are patuletin and patulintrin (patuletin reduces capillary permeability, has hypotensive effect, shows P-vitamin activity) [24, 29].

In addition, Tagetes patula flowers contain other antioxidants - tocopherols (0.6\%) and ascorbic acid (1.78\%), as well as phenol carboxylic acids - gallic, chlorogenic, coffee, chicory, ferulic, cinnamon. The content of macroand microelements in the flowers of marigolds is 47.0 and $7.28 \%$ (in terms of ash), respectively [30, 31].

Despite the useful properties of marigolds, there are contraindications to their use. It is not recommended to use the plant in the first trimester of pregnancy, during lactation, children under 3 years of age, patients with eczema, with individual intolerance and people prone to allergies [8, 23-25].
Given these useful properties of Tagetes patula colors, it is advisable to use their water-alcohol extracts as part of cosmetic products for toning the skin as a source of bio-antioxidants and matting agents. Such extracts (after preliminary distillation of ethyl alcohol) have already shown a positive result in the production of probiotic whey-strawberry drinks of preventive use) [32].

\section{Methods of research}

To optimize the formulation composition of the probiotic cosmetic agent for the toning of oily skin, the methodology of the response surface is used [33]. This method is a set of mathematical and statistical techniques aimed at modeling technological processes and finding the relationships of experimental predictor series in order to optimize the response function $\hat{y}(x, b)$, which in general is described by the following polynomial:

$$
\hat{y}(x, b)=b_{0}+\sum_{l=1}^{n} b_{l} x_{l}+\sum_{k=1}^{n} b_{k} x_{k}^{2}+\sum_{i=1}^{n-1} \sum_{j=i+1}^{n} b_{i j} x_{i} x_{j},
$$

where $x \in R^{n}$ - vector of variables, $b$ - vector of parameters.

Simulation and processing of experimental data is performed in the environment of the software package Statistica 10 (StatSoft, Inc., USA).

As part of the probiotic cosmetic for toning of oily skin, the mass fraction of the water-alcohol extract of dried flowers Tagetes patula and acid whey is varied, and the mass fraction of mineral water «Malyatko» is determined by the formula:

$$
C m w=100-(C t p+C a w)
$$

where Cmж, Ctp, Caw - mass fraction of mineral water water-alcohol extract of dry colors Tagetes patula and acid whey (\%), respectively.

For the preparation of cosmetics, the raw ingredients are mixed in the required quantities and mixed for 5-10 minutes. Antioxidant activity (AA, act. units) and active acidity ( $\mathrm{pH}, \mathrm{pH}$ units) are determined in the obtained lotions and tonics.

The ratio of raw ingredients in probiotic cosmetics for toning of oily skin is considered optimal, at which the maximum antioxidant activity of the agent is achieved and the normalized value of active acidity is achieved. The normalized value of active acidity is taken to be $\mathrm{pH} 4.5-5.2 \mathrm{PH}$ units, corresponds to that for the skin of the face [7].

On the basis of the developed recommendations, a probiotic cosmetic agent for toning oily skin with an optimal ratio of raw ingredients is produced and the main quality indicators are determined therein. Based on the results of the studies, conclusions are drawn about the possibility of producing new types of cosmetic products for toning oily skin with probiotic properties.

When performing studies, an antioxidant activity of probiotic cosmetics is determined by the method described in [34, 35]; active acidity - by potentiometric method according to [36].

\section{Research results}

Criteria for optimizing the composition of probiotic cosmetics for toning oily skin have been selected by anti- 
oxidant activity ( $A A$, act. units) and active acidity ( $\mathrm{pH}$, $\mathrm{pH}$ units). Independent varied factors in the experiment are the mass fraction of acid whey $\left(S_{a w}, \%\right)$ and the mass fraction of the water-alcohol solution of dry colors Tagetes patula (Ctp, \%).

To model the antioxidant activity ( $A A$, act. units) and active acidity ( $\mathrm{pH}, \mathrm{pH}$ units), the response function is chosen, which has the form of a second-order polynomial:

$$
\begin{aligned}
& A A=b_{0}+b_{1} \cdot C t p+b_{11} \cdot C t p^{2}+b_{2} \cdot C a w+ \\
& +b_{22} \cdot C^{2} w^{2}+b_{12} \cdot C t p \cdot C a w \\
& p H=b_{0}+b_{1} \cdot C t p+b_{11} \cdot C t p^{2}+b_{2} \cdot C a w+ \\
& +b_{22} \cdot \text { Caw }^{2}+b_{12} \cdot C t p \cdot C a w
\end{aligned}
$$

where $A A$ - antioxidant activity, act. units; $\mathrm{pH}$ - active acidity, $\mathrm{pH}$ units; $b_{0}-$ a constant; $C t p$ - mass fraction of water-alcohol solution of dry flowers Tagetes patula, \%; Caw - mass fraction of acid whey, $\% ; b_{1}, b_{11}, b_{2}, b_{22}$, $b_{12}$ - the coefficients for each element of the polynomial.

In the studies, the central composite rotatable design is used [33]. The choice of levels and intervals of variation of factors is carried out taking into account the recommendations for development of cosmetic tonic for oily skin:

- mass fraction of water-alcohol extract of dry flowers Tagetes patula varies within 6.67-40.02\% (this concentration of the extract provided the content of ethyl alcohol in the target product of 5-30\%);

- mass fraction of acidic whey is varied within the limits of $46.67-59.98 \%$. At the maximum content of acidic whey in the cosmetic means there is no mineral water «Malyatko», and with a minimum content of acidic whey the mineral water content is $46.66 \%$.

The design matrix and the experimental values of the response functions are presented in Table 1. To reduce the influence of systematic errors caused by external conditions, the sequence of experiments is randomized.

To test the significance of the regression coefficients (3) and (4), the Pareto charts are built (shown in Fig. 1, L linear effect, $Q$ - quadratic effect).

Design matrix and response functions

\begin{tabular}{|c|c|c|c|c|c|c|}
\hline \multirow{2}{*}{$\begin{array}{c}\text { No. of } \\
\text { experi- } \\
\text { ment }\end{array}$} & $\begin{array}{c}\text { Mass fraction of water-alco- } \\
\text { hol extract of dried flowers } \\
\text { Tagetes patula, (Ltp) }\end{array}$ & \multicolumn{2}{|c|}{$\begin{array}{c}\text { Mass fraction of acid } \\
\text { whey, }(\text { Caw) }\end{array}$} & $\begin{array}{c}\text { Antioxidant } \\
\text { activity }(A A) \text {, } \\
\text { act. units }\end{array}$ & $\begin{array}{c}\text { Active } \\
\text { acidity }(p H)_{n} \\
\text { pH units }\end{array}$ \\
\cline { 2 - 5 } & Coded level & $\%$ & Coded level & $\%$ & & \\
\hline 1 & -1 & 11.52 & -1 & 48.61 & 26.30 & 4.48 \\
\hline 2 & 0 & 23.34 & $-\sqrt{2}$ & 46.67 & 30.00 & 4.60 \\
\hline 3 & +1 & 35.16 & -1 & 48.61 & 33.00 & 4.70 \\
\hline 4 & $+\sqrt{2}$ & 40.02 & 0 & 53.33 & 40.66 & 4.77 \\
\hline 5 & +1 & 35.16 & +1 & 58.05 & 41.00 & 4.69 \\
\hline 6 & 0 & 23.34 & $+\sqrt{2}$ & 59.98 & 38.66 & 4.59 \\
\hline 7 & -1 & 11.52 & +1 & 58.05 & 22.66 & 4.46 \\
\hline 8 & $-\sqrt{2}$ & 6.67 & 0 & 53.33 & 18.33 & 4.41 \\
\hline 9 & 0 & 23.34 & 0 & 53.33 & 31.66 & 4.56 \\
\hline 10 & 0 & 23.34 & 0 & 53.33 & 33.30 & 4.57 \\
\hline 11 & 0 & 23.34 & 0 & 53.33 & 31.85 & 4.56 \\
\hline 12 & 0 & 23.34 & 0 & 53.33 & 32.90 & 4.57 \\
\hline
\end{tabular}
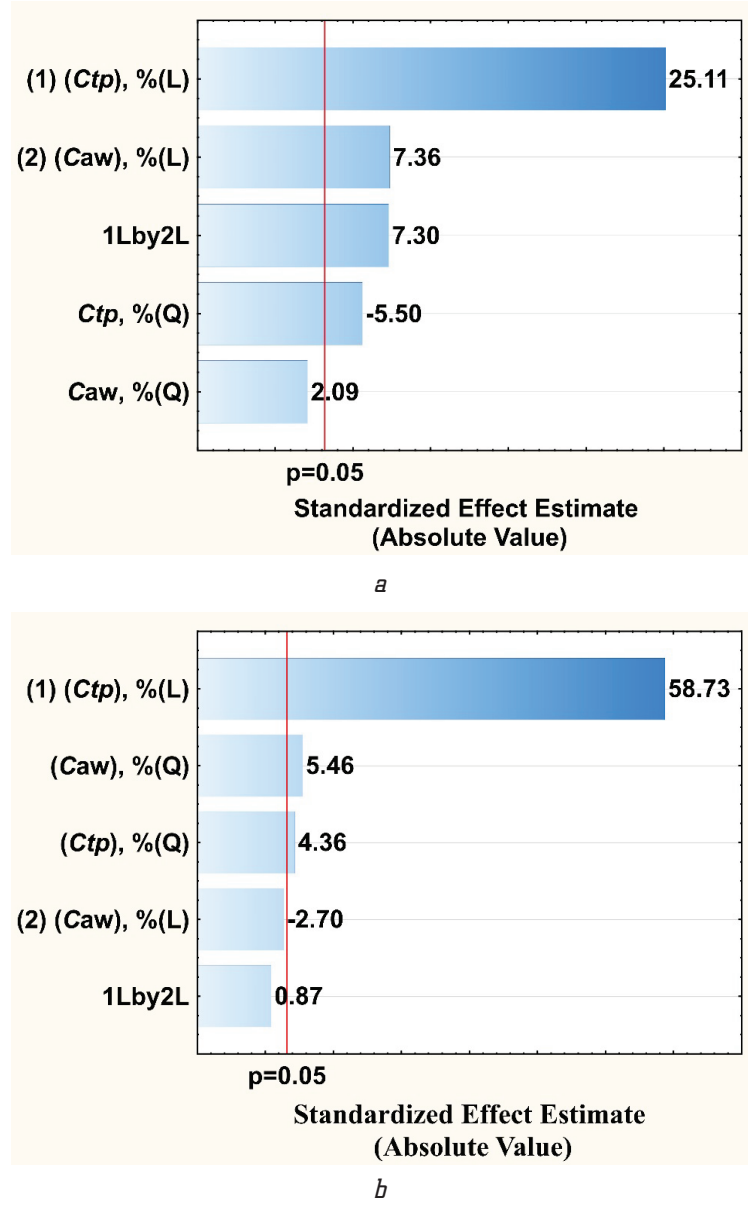

Fig. 1. Pareto charts for checking the significance of the coefficients: $a-$ regression (3); $b$ - regression (4)

The Pareto charts diagrams (Fig. 1) show standardized coefficients, sorted by absolute values. Analysis of the data in Fig. 1, $a$, indicates that the quadratic mass fraction of acidic whey (Saw, K) for regression (3) is insignificant. The column for estimating this effect does not cross the vertical line, is a $95 \%$ confidence probability. With this

in mind, this regression member is eliminated

Table 1 from the model (3). For regression (4), according to the data in Fig. 1, $b$, an insignificant portion of acidic whey is a quadratic linear (Saze, $L$ ) and the effect of the interaction of the mass fractions of the extract of Tagetes patula and acid whey - (1Lby $2 L)$. Therefore, these regression terms are eliminated from the model (4).

The equations obtained with the calculated coefficients have the form:

$$
\begin{aligned}
& A A=53.009-1.547 \cdot C t p-0.014 \cdot C_{t p}{ }^{2}- \\
& -0.777 \cdot C a w+0.052 \cdot C t p \cdot C a w, \\
& p H=4.396+0.008 \cdot C t p+ \\
& +0.00005 \cdot C^{2} p^{2}-0.00001 \cdot \text { Caw }^{2} .
\end{aligned}
$$

The adequacy of the developed models (5) and (6) is checked by the method of variance analysis. The significance level of lack of fit for both models is $p>0.05$. The values of the 
coefficient of determination for both models are close to unity: for the model (5) $R^{2}=0.960$ and $R_{a d j}^{2}=0.937$; for the model (6), $R^{2}=0.984$ and $R_{a d j}^{2}=0.978$. Thus, the presented results indicate that the models adequately describe the experiment.

The combined effect of the mass fraction of acid whey (Saw, \%) and the mass fraction of the water-alcohol extract of dried flowers Tagetes patula (Ctp, \%) on antioxidant activity ( $A A$, act. units) and active acidity ( $\mathrm{pH}, p H$ units) of the cosmetic agent for toning of oily skin are described by the polynomials (5) and (6) and shown in Fig. 2, 3.
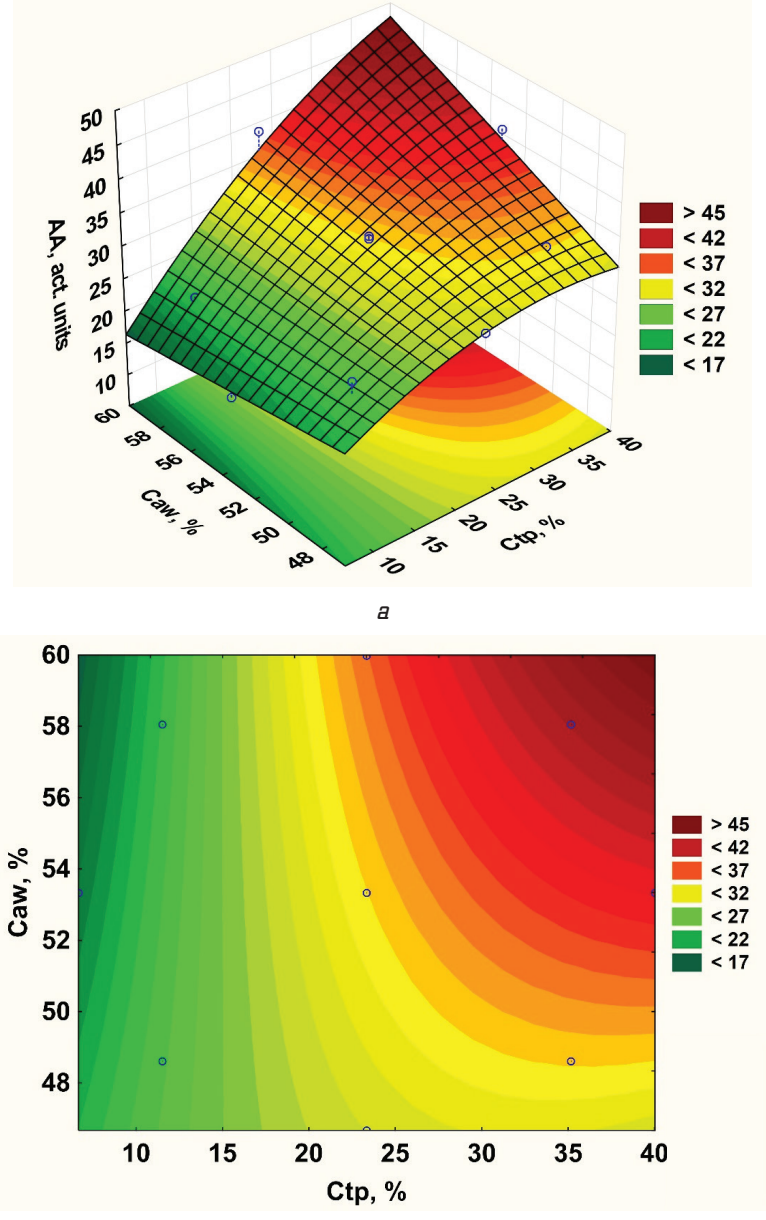

$b$

Fig. 2. Dependence of the antioxidant activity of the probiotic cosmetic product for the toning of oily skin - $A A$ (act. units) from the mass fraction of the water-alcohol extract of dried flowers Tagetes patula - Ctp (\%) and the mass fraction of acid whey - Saw (\%): $a-$ response surface; $b$ - contour plot

An increase in the composition of the target cosmetic mass portion of the extract of the colors Tagetes patula and acid whey contributes to a significant increase in its antioxidant activity - from 22.0 to 45.6 act. units (Fig. 1, $a, b$ ). More significantly affects the increase in the antioxidant activity of the probiotic cosmetic agent in the increase in its composition of antioxidants (carotenoids, flavonols and catechins, introduced with an extract of flowers of marigolds). However, an increase in the mass fraction of acidic whey also causes an increase in the investigated indicator. This proves the correctness of the assumption that probiotics accumulate metabolic products (including vitamins) during the fermentation of illuminated whey, which also has an antioxidant effect. The maximum value of antioxidant activity (45.6 act. units) has a probiotic cosmetic product that contains $40.02 \%$ of the water-alcohol extract of dried flowers Tagetes patula and $59.98 \%$ of probiotic acid whey and does not contain mineral water. At the indicated concentrations of raw ingredients, the probiotic cosmetic contains $30 \%$ of ethyl alcohol, that is, according to the classification given in [6], refers to cosmetic lotions.
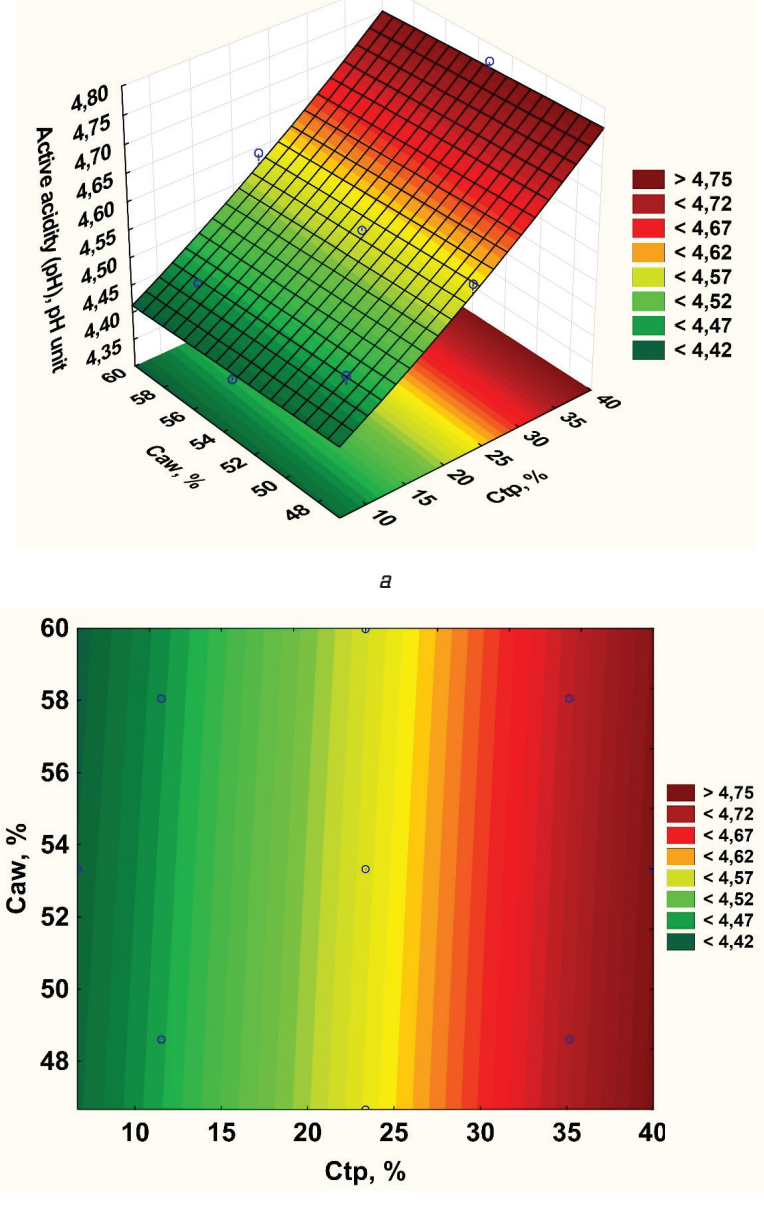

Fig. 3. Dependence of the active acidity of the probiotic cosmetic agent for the toning of oily skin - AA (act. unit) from the mass fraction of the water-alcohol extract of dried flowers Tagetes patula - Ctp (\%) and the mass fraction of acid whey - Saw (\%): $a$ - response surface; $b$ - contour plot

An increase in the mass fraction of the Tagetes patula extract in the cosmetic composition for the toning of oily skin causes an increase in the $\mathrm{pH}$ of the target product from 4.41 to $4.76 \mathrm{pH}$ units (Fig. 2, $a, b$ ). This is because the extract contains practically no organic acids. An increase in the content of an acidic whey in the composition of a cosmetic agent does not significantly affect the value of active acidity (Fig. 2, $a, b$ ). This is probably due to a slight increase in the concentration of lactic acid in the composition of the desired cosmetic product with an increase in the content of acid whey - from 0.46 to $0.59 \%$, as well as the buffer properties of the substances that make up the water-alcohol extract of flowers of marigolds. Cosmetic lotion with the maximum value of antioxidant activity has an active acidity of $4.76 \mathrm{pH}$ units, corresponds to the limitations assumed in the experiment. 
Thus, the processing of polynomials (5) and (6) in Statistica 10 allows to determine the optimal values of the mass fractions of the water-alcohol extract of dry flowers Tagetes patula (Ctp, \%) and acid whey (Saw, \%) - 40.02 and $59.98 \%$. In these values, the antioxidant activity of the probiotic cosmetic lotion for the toning of oily skin has a maximum value of 45.6 act. units (Fig. 1), and the active acidity of the cosmetic product $(4.76 \mathrm{pH}$ units Fig. 2) corresponds to the limitations adopted in the experiments and requirements of DSTU 4093-2002 [6].

The main quality indicators of probiotic cosmetic lotion for toning of oily skin, produced by mixing raw ingredients in the optimal ratio, are given in Table 2.

Organoleptic and physicochemical parameters of the of DSTU 4093-2002 (Table 2). The developed cosmetic product has a pleasant light orange color and herbal aroma due to the transition to a water-alcohol extract of a part of the essential oil from dried flowers of marigold, therefore, the addition of other matting agents is not required.

Let's note that the microbiological characteristics of the developed product differ from those given in the regulatory documentation:

- in the developed probiotic cosmetic lotion, let's determine the number of viable monocyte cells of Bifidobacterium animalis $B b-12$ and mixed cultures of Lactobacillus acidophilus La-5 + Streptococcus thermophilus, which are not standardized in DSTU 4093-2002 [6]; produced probiotic cosmetic lotion meet the requirements

- does not detect the number of mesophilic aerobic and facultative-anaerobic microorganisms in the probiotic cosmetic lotion, since the bacterial concentrate FD DVS ABT-2, used for the production of acid whey, includes mixed cultures of Lactobacillus acidophilus La-5 + Streptococcus thermophilus, which are facultative anaerobes and are present in the product in an amount of 5 times exceeds the norm established in DSTU 4093-2002 [6].

Therefore, for the introduction of the developed cosmetic lotion into the production, it is necessary to develop appropriate regulatory documents (technical conditions and technological instructions).

\section{SWOT analysis of research results}

Strengths. The strengths include:

- naturalness of the product;

- the consumer's curiosity towards a new cosmetic;

- high probiotic properties and improved microbiological indices.

Weaknesses. The weaknesses are:

- poor consumer awareness of the new cosmetic and its benefits;

- limited time and conditions for storing the lotion (not more than 40 days at a temperature of $2-6{ }^{\circ} \mathrm{C}$ ).

Opportunities. As for the opportunities of the new product, there are:

Table 2

Organoleptic, physicochemical and microbiological indicators of probiotic cosmetic lotion for toning of oily skin in comparison with the requirements of DSTU 4093-2002 ( $n=3, p \leq 0.05$ )

\begin{tabular}{|c|c|c|}
\hline \multirow[b]{2}{*}{ Indicator } & \multicolumn{2}{|c|}{ Characteristic of an indicator } \\
\hline & $\begin{array}{l}\text { For the developed probiotic } \\
\text { cosmetic lotion }\end{array}$ & $\begin{array}{l}\text { For cosmetic lotion by } \\
\text { DSTU 4093-2002 [6] }\end{array}$ \\
\hline \multicolumn{3}{|c|}{ Organoleptic indicators } \\
\hline Appearance & $\begin{array}{l}\text { Homogeneous single-phase } \\
\text { transparent liquid without tur- } \\
\text { bidity and sediment }\end{array}$ & $\begin{array}{l}\text { Homogeneous single-phase or mul- } \\
\text { tiphase liquid (emulsion). There is } \\
\text { slight turbidity or precipitation }\end{array}$ \\
\hline Color & $\begin{array}{l}\text { Light orange color, homoge- } \\
\text { neous throughout the medium }\end{array}$ & $\begin{array}{l}\text { Must match the color of the product } \\
\text { of a specific name }\end{array}$ \\
\hline Smell & $\begin{array}{l}\text { With a slight smell of ethyl al- } \\
\text { cohol and a slight floral aroma }\end{array}$ & $\begin{array}{l}\text { Must respond with the smell of } \\
\text { a product of a specific name }\end{array}$ \\
\hline \multicolumn{3}{|c|}{ Physical and chemical indicators } \\
\hline Volume fraction of ethyl alcohol, \% & $29.9-30.1$ & $20.1-80.0$ \\
\hline Hydragen index $(\mathrm{pH})$ & $4.7-4.8$ & 3.0-8.5 \\
\hline Colloidal stability & Stable & Stable \\
\hline Thermal stability & Stable & Stable \\
\hline \multicolumn{3}{|c|}{ Microbiological indicators } \\
\hline $\begin{array}{l}\text { The number of mesophilic aerobic } \\
\text { and facultative-anaerobic microor- } \\
\text { ganisms, CFU/cm }\end{array}$ & Not identified & 1000 \\
\hline $\begin{array}{l}\text { The number of viable cells of Bifido- } \\
\text { bacterium animalis } B b-12, \text { CFU/ } \mathrm{cm}^{3}\end{array}$ & $(1.0-2.2) \cdot 10^{8}$ & Not standardized \\
\hline $\begin{array}{l}\text { The number of viable cells of mixed } \\
\text { cultures of Lactobacillus acidophilus } \\
\text { La-5 + Streptocaccus thermophilus, } \\
\text { CFU/ } \mathrm{cm}^{3}\end{array}$ & $(2.5-4.0) \cdot 10^{8}$ & Not standardized \\
\hline $\begin{array}{l}\text { Bacteria of the Enterobactereaceae } \\
\text { family in } 1 \mathrm{~cm}^{3}\end{array}$ & Absent & Absent \\
\hline Staphylacaccus aureus in $1 \mathrm{~cm}^{3}$ & Absent & Absent \\
\hline Pseudomonas aeruginosa in $1 \mathrm{~cm}^{3}$ & Absent & Absent \\
\hline Quantity of yeasts and molds, CFU/ $\mathrm{cm}^{3}$ & $<10$ & No more than 100 \\
\hline
\end{tabular}

- presence of antimicrobial agents in cosmetics-analogs;

- the absence of probiotic properties in products that are analogues of competitors;

- availability of unsaturated segments of markets;

- lack of Ukrainian probiotic cosmetics and a narrow range of similar imported products.

Threats. Threats when a new product enters the consumer market:

- possibility of the appearance of new cosmetics and substitute products;

- growing competitive pressure petitors;

- decline in the purchasing power of the population;

- unstable economic and political situation in Ukraine;

- consumer conservatism.

Based on the SWOT analysis, the following strategic solutions are proposed:

- access to new markets or marpricing policy for the promotion of a new cosmetic lotion on the market. Carry out activities to develop the consumer himself in the use of probiotic cosmetics, encourage him to buy this product, as well as the active role of marketing. When carrying out marketing due to the emergence of new comket segments. Provides a flexible 
activities, it is necessary to emphasize the naturalness of the cosmetic product and the presence of live cultures of lacto- and bifidobacteria in it, which cause high probiotic properties and antibacterial effect. Attention should also be paid to the design of packaging and the informative nature of the marking;

- expansion of the assortment line of probiotic cosmetics due to the use of water-alcohol extracts of other medicinal plants with a high content of bioantioxidants; - the weak side, namely, the high price in comparison with cosmetic lotions and tonics presented in the market, can be solved at the expense of reduction of the price of own product by increase in volumes of manufacture and logistics of delivery process of the illuminated whey from milk processing enterprises on cosmetic. The increase in demand for a new probiotic cosmetic lotion will occur as a result of the dissemination of information on the naturalness of the product and its positive effect on the condition of oily skin of the face;

- the weak side of «poor consumer awareness of the new cosmetic and its benefits» it is proposed to solve through the implementation of a set of measures. They must begin at the initial stage of cosmetic development and continue at the entire stage of its product circulation. The measures should be aimed at informing potential consumers about the properties of a new cosmetic product and the influence of probiotics on the state of human skin health;

- to reduce the impact of such factors as «the emergence of new competitors» and «growing competitive pressure», it is advisable to use a flexible pricing policy, to develop new sales markets, to provide for the active role of marketing and expansion of the range. As for the «purchasing power» factor, measures should be taken to position a new cosmetic product among potential consumers, measures to develop consumers themselves in the use of probiotic cosmetics;

- the weak side «limited time and conditions for storing the lotion» can be solved by using a package with a volume of no more than $100 \mathrm{~cm}^{3}$, which will allow the consumer to fully use the probiotic cosmetic lotion before the end of its shelf life. It is expedient to organize realization of the developed product through a network of specialized shops, beauty salons or offices, in which it is possible to provide the necessary storage conditions;

- promotion of probiotic cosmetic lotion by means of merchandising - if it is not possible to use direct advertising for promotion of a new product, it is advisable to stimulate sales with the help of indirect communications, which are less expensive, but not less effective.

\section{Conclusions}

1. The antioxidant activity and the active acidity of the probiotic cosmetic agent for the toning of oily skin are determined. It is shown that when the weight fraction of a water-alcohol solution of dry colors of Tagetes patula and acid whey increases in the composition of the desired cosmetic agent, the studied parameters increase.

2. It is found that the maximum antioxidant activity (45.6 act. units) and the normalized value of active acidity (4.76 pH units), a probiotic cosmetic for toning of oily skin has an optimal content of raw ingredients in it.
Namely: $59.98 \%$ of the acid whey obtained using probiotic cultures of lacto- and bifidobacteria in the composition of the direct bacterial concentrate FD DVS ABT-2, and $40.02 \%$ of the water-alcohol extract of the dry flowers of Tagetes patula.

3. It is determined that the organoleptic and physicochemical quality indicators of the probiotic cosmetic for toning of oily skin, produced using the raw ingredients in the optimal ratio, meets the requirements of DSTU 4093-2002. Developed product By the content of ethyl alcohol can be attributed to cosmetic lotions. Microbiological indices of the developed probiotic cosmetic lotion differ from those in DSTU 4093-2002, therefore, for the introduction of it into production, it is necessary to develop appropriate regulatory documents.

\section{References}

1. Jeong, J. H. Probiotic Lactic Acid Bacteria and Skin Health [Text] / J. H. Jeong, C. Y. Lee, D. K. Chung // Critical Reviews in Food Science and Nutrition. - 2015. - Vol. 56, No. 14. - P. 2331-2337. doi:10.1080/10408398.2013.834874

2. Tonik dlia litsa: sostav, pol'za, populiarnye marki [Electronic resource] // MEDPORTAL.SU. - 2017. - Available at: \www/ URL: https://medportal.su/tonik-dlya-lica-sostav-polza-populyarnye-marki/

3. Fem, O. Tonik dlia litsa - o chiom umalchivaiut proizvoditeli [Electronic resource] / O. Fem // KOSMETOLOGA.NET. September 25, 2017. - Available at: \www/URL: https:// kosmetologa.net/tonik-dlya-litsa/

4. Chitaem etiketku: tonik dlia litsa [Electronic resource] // Medik. Katalog goroda Sumy. - 2017. - Available at: \www/URL: https:// www.medik.sumy.ua/articles/chitaem-etiketku-tonik-dlya-lica

5. Chto vhodit v sostav tonika? [Electronic resource] // Zhenskii zhurnal BeautyInfo. - 2017. - Available at: \www/URL: http://beautyinfo.com.ua/m0c3i3109.html

6. DSTU 4093-2002. Losiony i toniky kosmetychni [Text]. - Introduced: 03.06.2002. - Kyiv: Derzhstandart Ukrainy, 2002. -8 p.

7. Dreno, B. Microbiome in healthy skin, update for dermatologists [Text] / B. Dreno, E. Araviiskaia, E. Berardesca, G. Gontijo, M. Sanchez Viera, L. F. Xiang, R. Martin, T. Bieber // Journal of the European Academy of Dermatology and Venereology. 2016. - Vol. 30, No. 12. - P. 2038-2047. doi:10.1111/jdv.13965

8. Gong, Y. Investigation into the antioxidant activity and chemical composition of alcoholic extracts from defatted marigold (Tagetes erecta L.) residue [Text] / Y. Gong, X. Liu, W.-H. He, H.-G. Xu, F. Yuan, Y.-X. Gao // Fitoterapia. - 2012. - Vol. 83, No. 3. - P. 481-489. doi:10.1016/j.fitote.2011.12.013

9. DSTU 4554:2006. Syr kyslomolochnyi. Tekhnichni umovy [Text]. - Introduced: 01.01.2007. - Kyiv: Derzhstandart Ukrainy, 2007. - 10 p.

10. Fuchs-Tarlovsky, V. Probiotics in dermatologic practice [Text] / V. Fuchs-Tarlovsky, M. F. Marquez-Barba, K. Sriram // Nutrition. - 2016. - Vol. 32, No. 3. - P. 289-295. doi:10.1016/ j.nut.2015.09.001

11. Goto, K. Clinical and Histopathological Evaluation of Dermatophagoides farinae-Induced Dermatitis in NC/Nga Mice Orally Administered Bacillus subtilis [Text] / K. Goto, D. Iwasawa, Y. Kamimura, M. Yasuda, M. Matsumura, T. Shimada // Journal of Veterinary Medical Science. - 2011. - Vol. 73, No. 5. P. 649-654. doi:10.1292/jvms.10-0457

12. Watanabe, T. Oral Administration of Lactic Acid Bacteria Isolated from Traditional South Asian Fermented Milk «Dahi» Inhibits the Development of Atopic Dermatitis in NC/Nga Mice [Text] / T. Watanabe, K. Hamada, A. Tategaki, H. Kishida, H. Tanaka, M. Kitano, T. Miyamoto // Journal of Nutritional Science and Vitaminology. - 2009. - Vol. 55, No. 3. - P. 271-278. doi:10.3177/jnsv.55.271

13. Rosenfeldt, V. Effect of probiotic Lactobacillus strains in children with atopic dermatitis [Text] / V. Rosenfeldt, E. Benfeldt, S. D. Nielsen, K. F. Michaelsen, D. L. Jeppesen, N. H. Valerius, A. Paerregaard // Journal of Allergy and Clinical Immunology. - 2003. - Vol. 111, No. 2. - P. 389-395. doi:10.1067/ mai.2003.389 
14. Elbe-Burger, A. Overexpression of IL-4 Alters the Homeostasis in the Skin [Text] / A. Elbe-Burger, S. Olt, G. Stingl, A. Egyed, R. Klubal, U. Mann, K. Rappersberger, A. Rot // Journal of Investigative Dermatology. - 2002. - Vol. 118, No. 5. - P. 767-778. doi:10.1046/j.1523-1747.2002.01753.x

15. Stokes, J. H. The Effect on The Skin of Emotional and Nervous States: Theoretical and Practical Consideration of a Gastrointestinal Mechanism [Text] / J. H. Stokes, D. H. Pillsbury // Archives of Dermatology and Syphilology. - 1930. - Vol. 22, No. 6. - P. 962-993. doi:10.1001/archderm.1930.01440180008002

16. Zhu, D. L. Meta analysis of lactic acid bacteria as probiotics for the primary prevention of infantile eczema [Text] / D. L. Zhu, W. X. Yang, H. M. Yang // Chinese Journal of Contemporary Pediatrics. - 2010. - Vol. 12, No. 9. - P. 734-739.

17. Kim, H. H. Eicosapentaenoic acid inhibits TNF- $\alpha$-induced matrix metalloproteinase-9 expression in human keratinocytes, HaCaT cells [Text] / H. H. Kim, Y. Lee, H. C. Eun, J. H. Chung // Biochemical and Biophysical Research Communications. - 2008. Vol. 368, No. 2. - P. 343-349. doi:10.1016/j.bbrc.2008.01.062

18. Piccardi, N. Nutrition and nutritional supplementation [Text] N. Piccardi, P. Manissier // Dermato-Endocrinology. - 2009. Vol. 1, No. 5. - P. 271-274. doi:10.4161/derm.1.5.9706

19. Segawa, S. Oral Administration of Heat-Killed Lactobacillus brevis SBC8803 Ameliorates the Development of Dermatitis and Inhibits Immunoglobulin E Production in Atopic Dermatitis Model NC/Nga Mice [Text] / S. Segawa, A. Hayashi, Y. Nakakita, H. Kaneda, J. Watari, H. Yasui // Biological \& Pharmaceutical Bulletin. - 2008. - Vol. 31, No. 5. - P. 884-889. doi:10.1248/bpb.31.884

20. Gueniche, A. Supplementation with oral probiotic bacteria maintains cutaneous immune homeostasis after UV exposure [Text] A. Gueniche, J. Benyacoub, T. M. Buetler, H. Smola, S. Blum // European Journal of Dermatology. - 2006. - Vol. 16, No. 5. P. 511-517.

21. Cinque, B. Effect of Bifidobacteriuminfantis on Interferon$\gamma$-Induced Keratinocyte Apoptosis: A Potential Therapeutic Approach to Skin Immune Abnormalities [Text] / B. Cinque, L. Di Marzio, D. N. Della Riccia, F. Bizzini, M. Giuliani, D. Fanini, C. De Simone, M. G. Cifone // International Journal of Immunopathology and Pharmacology. - 2006. - Vol. 19, No. 4. - P. 775-786. doi:10.1177/039463200601900407

22. Gagarina, Yu. Krem: spasibo, chto zhivoi [Text] / Yu. Gagarina // Kosmetolog. - 2016. - No. 3. - P. 74-76.

23. Faizi, S. Bioassay-guided isolation of antioxidant agents with analgesic properties from flowers of Tagetes patula [Text] / S. Faizi, A. Dar, H. Siddiqi, S. Naqvi, A. Naz, S. Bano, N. Lubna // Pharmaceutical Biology. - 2011. - Vol. 49, No. 5. P. 516-525. doi:10.3109/13880209.2010.523006

24. Yasukawa, K. Effects of Flavonoids from French Marigold (Florets of Tagetes patula L.) on Acute Inflammation Model [Text] / K. Yasukawa, Y. Kasahara // International Journal of Inflammation. - 2013. - Vol. 2013. - P. 1-5. doi:10.1155/2013/309493

25. Politi, F. Anti-Candida Activity in Vitro of Tagetes patula L. (Asteraceae) Extracts [Text] / F. Politi, V. Watanabe, G. Figueira, R. Pietro // Planta Medica. - 2013. - Vol. 79, No. 10. doi:10.1055/s-0033-1348567

26. Ali, A. Chemical composition of Tagetes patula essential oil and its bioactivity against Aedes aegypti [Text] / A. Ali, N. Tabanca, B. Demirci, E. Amin, I. Khan // Planta Medica. - 2015. Vol. 81, No. 5. doi:10.1055/s-0035-1545156

27. Zuorro, A. New functional food products containing lutein and zeaxanthin from marigold (Tagetes erecta L.) flowers [Text] A. Zuorro, R. Lavecchia // Journal of Biotechnology. - 2010. Vol. 150. - P. 296-296. doi:10.1016/j.jbiotec.2010.09.247

28. Manke Natchigal, A. Quantification and characterization of lutein from Tagetes (Tagetes patula L.) and Calendula (Calendula officinalis L.) flowers [Text] / A. Manke Natchigal, A. C. Oliveira Stringheta, M. Correa Bertoldi, P. C. Stringheta // Acta Horticulturae. - 2012. - No. 939. - P. 309-314. doi:10.17660/actahortic.2012.939.40

29. Khalil, M. Stability and bioavailability of lutein ester supplements from Tagetes flower prepared under food processing conditions [Text] / M. Khalil, J. Raila, M. Ali, K. M. S. Islam, R. Schenk, J.-P. Krause, F. J. Schweigert, H. Rawel // Journal of Functional Foods. - 2012. - Vol. 4, No. 3. - P. 602-610 doi:10.1016/j.jff.2012.03.006
30. Ramakrishnan, P. Cognitive enhancing, anti-acetylcholinesterase, and antioxidant properties of Tagetes patula on scopolamine-induced amnesia in mice [Text] / P. Ramakrishnan, T. Chandrasekhar, P. Muralidharan // International Journal of Green Pharmacy. 2015. - Vol. 9, No. 3. - P. 167. doi:10.4103/0973-8258.161234

31. Martinez, R. Chemical Composition of Essential Oils and Toxicological evaluation of Tagetes erecta and Tagetes patula from Venezuela [Text] / R. Martinez, B. Diaz, L. Vasquez, R. Compagnone, S. Tillett, D. Canelon, F. Torrico, A. I. Suarez // Journal of Essential Oil Bearing Plants. - 2009. - Vol. 12, No. 4. - P. 476-481. doi:10.1080/0972060x.2009.10643747

32. Tkachenko, N. Modelling formulae of strawberry whey drinks of prophylactic application [Text] / N. Tkachenko, P. Nekrasov, S. Vikul, Y. Honcharuk // Food Science and Technology. 2017. - Vol. 11, No. 1. - P. 80-88. doi:10.15673/fst.v11i1.303

33. Myers, R. H. Response Surface Methodology: Process and Product Optimization Using Designed Experiments [Text] / ed. by R. H. Myers, D. C. Montgomery, C. M. Anderson-Cook. - Ed. 4. Hoboken, New Jersey: John Wiley \& Sons, 2016. - 856 p.

34. Tkahcenko, N. Optimization of formulation composition of health whey-based beverage [Text] / N. Tkahcenko, P. Nekrasov, S. Vikul // Eastern-European Journal of Enterprise Technologies. - 2016. - Vol. 1, No. 10 (79). - P. 49-57. doi:10.15587/ 1729-4061.2016.59695

35. Sposib vyznachennia biolohichnoi aktyvnosti obiektiv pryrodnoho pokhodzhennia [Electronic resource]: Patent UA $107506 \mathrm{C} 2$, IPC G 01 N 33/00 (2015.01) / Khomych H. P., Vikul S. I., Kaprel'iants L. V., Osypova L. A., Lozovska T. S.; assignee: Odessa National Academy of Food Technologies. - Appl. No. u 201302626; Filed 04.03.2013; Publ. 12.01.2015, Bull. No. 1. - Available at: \www/URL: http://uapatents.com/7-107506-sposib-viznachennyabiologichno-aktivnosti-obehktiv-prirodnogo-pokhodzhennya.html

36. GOST 26781-85. Moloko. Metody izmereniia pH [Text]. - Introduced: 01.01.1986. - Moscow: Izdatelstvo standartov, 1985. - 13 p.

\section{ОБОСНОВАНИЕ СОСТАВА ПРОБИОТИЧЕСКИХ КОСМЕТИЧЕСКИХ}

\section{СРЕДСТВ ДЛЯ ТОНИЗАЦИИ ЖИРНОЙ КОЖИ}

Показана целесообразность применения пробиотиков в натуральной косметике. Обоснованы оптимальные массовые доли кислой сыворотки и экстракта цветов Tagetes patula (59,98 и 40,02\% соответственно) как компонентов пробиотического косметического средства для тонизирования жирной кожи. Доказано, что разработанный пробиотический косметический лосьон натуральный, безопасный, характеризуется высокими органолептическими, нормированными физико-химическими показателями, улучшенными микробиологическими характеристиками.

Ключевые слова: пробиотическая косметика, тонизирование кожи, Bifidobacterium, Lactobacillus, водно-спиртовой экстракт, Tagetes patula, кислая сыворотка.

Tkachenko Nataliia, Doctor of Technical Sciences, Professor, De partment of Dairy Technology and Technology of Fats and PerfumeCosmetic Products, Odessa National Academy of Food Technologies, Ukraine, e-mail: nataliya.n-2013@yandex.ua, ORCID: https:// orcid.org/0000-0002-2557-3927

Vikul Svitlana, PhD, Assistant Professor, Department of Food Chemistry, Odessa National Academy of Food Technologies, Ukraine, e-mail: vizaj_vik@ukr.net, ORCID: https://orcid.org/0000-0002-6753-5769

Sevastyanova Elena, PhD, Assistant Professor, Department of Dairy Technology and Technology of Fats and Perfume-Cosmetic Products, Odessa National Academy of Food Technologies, Ukraine, e-mail: elena.vladimirovn.sevastyanova@gmail.com, ORCID: https:// orcid.org/0000-0001-7485-6985

Dets Nadiya, PhD, Assistant Professor, Department of Dairy Technology and Technology of Fats and Perfume-Cosmetic Products, Odessa National Academy of Food Technologies, Ukraine, e-mail: dets.nadin@gmail.com,ORCID: https://orcid.org/0000-0003-4524-7560

Honcharuk Yana, Department of Dairy Technology and Technology of Fats and Perfume-Cosmetic Products, Odessa National Academy of Food Technologies, Ukraine, e-mail: yana.goncharuk.onaft@gmail.com, ORCID: https://orcid.org/0000-0003-2988-421X 